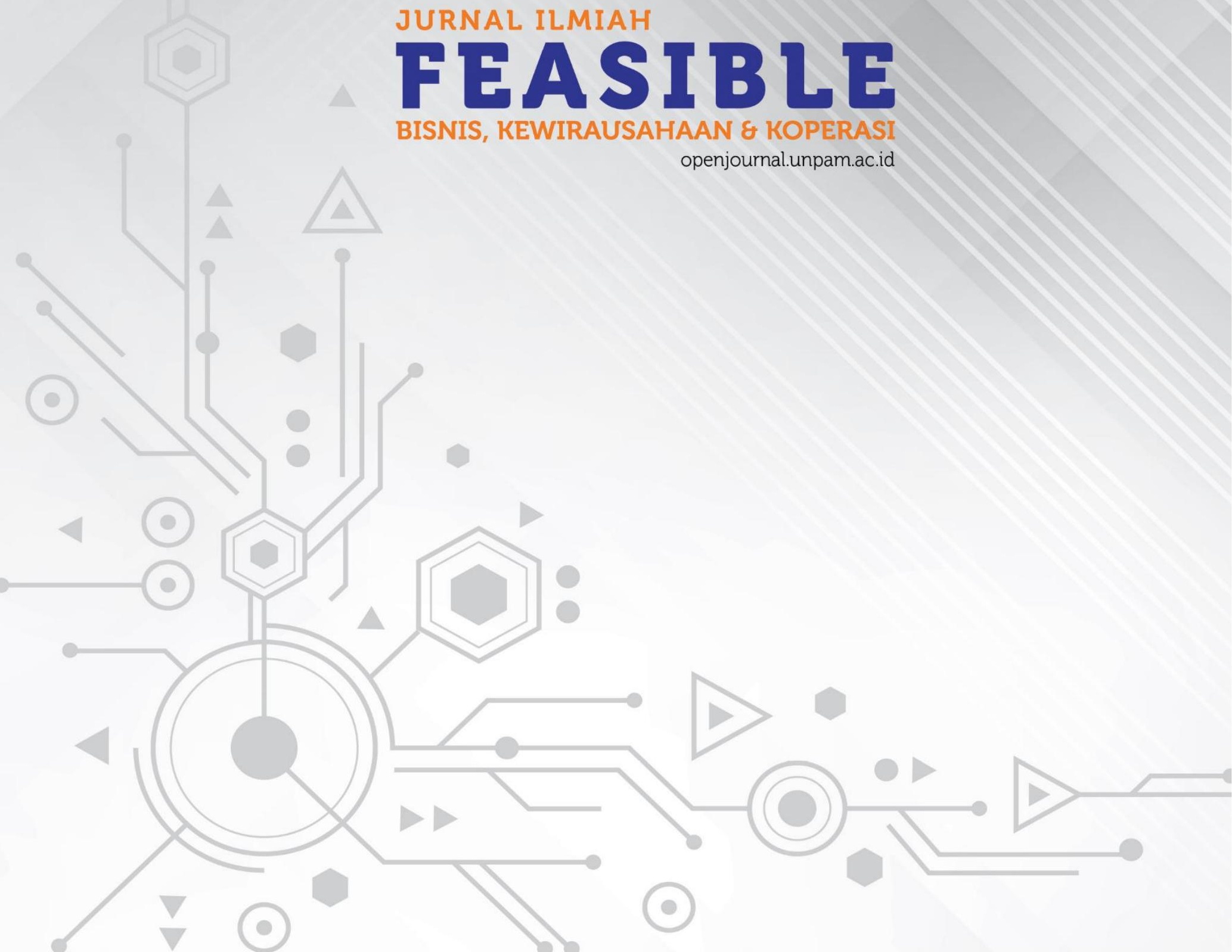


P-ISSN:2655-9811, E-ISSN:2656-1964

J. Feasible., Vol. 2, No.2, Agustus 2020 (126-139)

(0) 2019 Pusat InkubasiBisnis dan Kew irausahaan

Universitas Pamulang (PINBIKUNPAM)

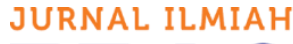

FEASIBLE

Fests

\title{
PENGARUH KUALITAS PRODUK DAN STRATEGI PEMASARAN \\ TERHADAP KEPUTUSAN PEMBELIAN PERANGKAT PARKIR PADA PT TRI WAHANA SOLUSINDO
}

\author{
Sugeng Widodo') ,Epa Nur Hasanah²) \\ Fakultas Ekonomi, Universitas Pamulang \\ dosen01632@unpam.ac.id
}

\begin{abstract}
Abstrak
Tujuan pada penelitian ini adalah untuk mengetahui pengaruh kualitas produk dan strategi pemasaran terhadap keputusan pembelian pada PT Tri Wahana Solusindo. Sifat penelitian deskriptif kuantitatif dengan pendekatan analisis kuantitatif. Teknik sampling yang digunakan adalah accidental sampling/incidental sampling dengan sampel sebanyak 83 responden. Analisa data yang digunakan meliputi uji validitas, uji reliabilitas, uji asumsi klasik (homogenitas, hetreoskedastisitas, multikolinieritas), uji simultan ( $F$ ), uji parsial ( $(t)$ dan uji determinasi. Hasil penelitian, kualitas produk dan strategi pemasaran secara parsial dan simultan berpengaruh terhadap keputusan pembelian dengan persamaan regresi $Y=3.573+0.474 X_{1}+O .280 X_{2}$ dengan koefisien determinasi sebesar $53,7 \%$, sedangkan sisanya sebesar 46,3\% dipengaruhi variabel variabel lain. Uji hipotesis diperoleh nilai F hitung $>$ F tabel atau $(45,318>3,11)$.
\end{abstract}

Kata Kunci: Kualitas Produk; Strategi Pemasaran; Keputusan Pembelian.

\begin{abstract}
The purpose of this study was to determine the effect of product quality and marketing strategies on purchasing decisions at PT Tri Wahana Solusindo. The nature of quantitative descriptive research with a quantitative analysis approach. The sampling technique used was accidental sampling / incidental sampling with a sample of 83 respondents. Data analysis used includes validity test, reliability test, classic assumption test (homogeneity, heteroscedasticity, multicollinearity), simultaneous test $(F)$, partial test $(t)$ and determination test. The results showed that product quality and marketing strategies partially and simultaneously affected purchasing decisions with the regression equation $Y=3.573+0.474 X 1+0.280 X 2$ with a determination coefficient of $53.7 \%$, while the remaining $46.3 \%$ was influenced by other variables. Hypothesis testing obtained the value of $F$ count $>$ F table or (45.318> 3.11).
\end{abstract}

Keywords: Product Quality; Marketing Strategy; Purchasing Decisions. 


\section{PENDAHULUAN}

Tempat parkir dan sistem pengaturan perparkiran adalah komponen penting dan tidak dapat dipisahkan dalam pelayanan sebuah fasilitas umum. Keberadaan sistem perparkiran yang baik akan mendukung fasilitas umum yang digunakan oleh banyak pihak. Sistem parkir yang baik mencerminkan kebaikan sistem yang lebih luas dalam fasilitas umum tersebut. Keamanan, kemudahan dan kenyamanan adalah faktor yang diharapkan oleh pengguna fasilitas umum. Oleh karena itu jika sistem perparkiran tidak memberikan keamanan, kemudahan dan kenyamanan bagi pengguna fasilitas umum, maka aktifitas dalam fasilitas umum tersebut akan terganggu. Pemilihan metode pelayanan yang baik pada sistem perparkiran akan menentukan keamanan, kemudahan dan kenyamanan fasilitas umum tersebut. Perusahaan-perusahaan baik besar maupun kecil telah berbondong-bondong untuk menggunakan bantuan ilmu pengetahuan dan teknologi dalam mendukung proses operasional perusahaan. Keberadaan komputer dalam mendukung kegiatan operasional perusahaan telah meningkatkan efisiensi tenaga dan waktu.Salah satu contoh penerapan yang paling sering dijumpai dalam kehidupan sehari-hari adalah penerapan program komputer dalam mengatur perparkiran di mal, plaza, gedung dan hotel.Akhir-akhir ini, hampir seluruh mal, plaza, gedung dan hotel yang ada di kota -kota besar ini menggunakan penerapan program komputer untuk mengatur proses perparkiran. Program komputer tersebut sering disebut sebagai Sistem Informasi Perparkiran. Sebelumnya, jika menggunakan proses manual untuk melakukan proses pencatatan kendaraan yang masuk dan keluar, maka akan memakan waktu yang cukup lama untuk melakukan proses analisis terhadap data kendaraan tersebut sehingga tidak efisien.Kemungkinan lainnya yang dapat terjadi yaitu data yang dicatat pada lembaran kertas tersebut dapat hilang, kotor, ataupun terbakar.

Maka untuk mengatasi kekurangankekurangan tersebut, banyak perusahaan pengelolaan perparkiran telah beralih ke program komputer. Data kendaraan yang masuk dan keluar akan di-input oleh operator ke dalam komputer. Kemudian, berdasarkan data kendaraan yang di-input tersebut, program komputer akan menganalisis dan memberikan berbagai laporan yang dibutuhkan oleh manajemen perusahaan.

Dengan adanya program komputer ini, maka laporan-laporan yang didapatkanakan jauh lebih efektif, efisien dan akurat dibandingkan dengan menggunakan sistem manual.perkembang teknologi saat ini menyebabkan proses penyebaran dan pertukaran informasi dapat dilakukan dengan cepat secara global tanpa ada batasan 
waktu. Teknologi World Wide Web (WWW) atau Web sebagai salah satu jenis layanan yang disediakan oleh internet merupakan jenis layanan yang berkembang paling pesat dan paling banyak digunakan saat ini.

Tabel 1.1. Data Penjualan 2015-2018
\begin{tabular}{|l|c|c|c|c|}
\hline \multicolumn{1}{|c|}{ Tahun } & 2015 & 2016 & 2017 & 2018 \\
\hline Target & 100 & 100 & 100 & 100 \\
\hline Pencapaian & 75 & 90 & 95 & 70 \\
\hline Presentase & $0.75 \%$ & $0.90 \%$ & $0.95 \%$ & $0.70 \%$ \\
\hline
\end{tabular}

Divisi Pemasaran dan penjualan memegang peranan penting dan bertanggung jawab dalam mengawasi dan menjamin kelangsungan sektor penjualan dengan memberikan informasi yang tepat bagi perusahaan dan konsumen. Karena divisi pemasaran dan penjualan berinteraksi langsung dengan konsumen dan menjadi ujung tombak bagi perusahaan. Informasi harga jual sangat diperlukan keberadaannya oleh berbagai pihak, antara lain bagi pihak PT. Tri Wahana Solusindo sebagai bahan acuan harga jual bagi konsumen.

Oleh karenanya, diperlukan suatu sistem yang cepat, tepat, dan akurat sehingga PT. Tri Wahana Solusindo akan terpenuhi kebutuhan atau kepentingannya. Hal ini sangat penting karena keberadaan suatu website dapat membantu menyampaikan informasi produk dan harga secara detail kepada konsumen. Selain itu melalui website akan mengakses informasi yang dibutuhkan kapan saja dan dimana saja.

\begin{tabular}{|c|c|c|c|c|c|}
\hline \multicolumn{6}{|c|}{ Tabel 1.2 Keluhan Pelanggan } \\
\hline \multirow[b]{2}{*}{ Tahun } & \multicolumn{2}{|c|}{ Keluhan } & \multirow{2}{*}{$\begin{array}{l}\text { Jumlah } \\
\text { Keluhan }\end{array}$} & \multirow{2}{*}{$\begin{array}{l}\text { Jumlah } \\
\text { Pelanggan }\end{array}$} & \multirow{2}{*}{$\%$} \\
\hline & $\begin{array}{c}\text { Pc } \\
\text { Error }\end{array}$ & $\begin{array}{c}\text { Sistem } \\
\text { Eror }\end{array}$ & & & \\
\hline 2015 & 15 & 7 & 22 & 75 & $29 \%$ \\
\hline 2016 & 18 & 10 & 28 & 90 & $31 \%$ \\
\hline 2017 & 19 & 15 & 34 & 95 & $35 \%$ \\
\hline 2018 & 25 & 14 & 39 & 70 & $55 \%$ \\
\hline
\end{tabular}

Berdasarkan pemantauan yang dilakukan terhadap beberapa hal yang mempengaruhi keputusan pembelian oleh konsumen dalam membeli perangkat parkir, diantaranya yaitu konsumen melihat apakah produk tersebut berkualitas dan apakah lebih efisien dalam penerapan di lokasi parkir tersebut.

Dengan kualitas produk dan strategi pemasaran yang baik diharapkan akan terjadi komunikasi antara produsen dengan konsumen. Dengan adanya komunikasi tersebut diharapkan dapat memperoleh konsumen baru dan mempertahankan konsumen lama. Berdasarkan uraian tersebut, maka penelitian ini berjudul "Pengaruh Kualitas Produk Dan Strategi Pemasaran Terhadap Keputusan Pembelian Perangkat Parkir".

Sesuai dengan latar belakang di atas, maka penulis merumuskan masalah sebagai berikut:

1. PC Komputer sering error.

2. Program sistem komputer yang sering error 
3. Adanya pesaing atau kompetitor perusahaan perangkat parkir.

4. Kurangnya Divisi pemasaran dan penjualan menyebabkan lemahnya daya beli konsumen.

5. Strategi yang diterapkan kurang efektif.

6. Penjualan belum mencapai terget.

\section{METODE}

Adapun metode penelitian yang digunakan adalah metode penelitian bersifat deskriptif kuantitatif, penelitian dengan pendekatan analisis kuantitatif menekankan analisisnya pada data-data numerical (angka) yang diolah dengan metode statistik, dimana dalam penelitian ini yang menjadi variabel bebas $\left(\mathrm{X}_{1}\right)$ adalah kualitas produk dan $\left(\mathrm{X}_{2}\right)$ strategi pemasaran sedangkan variabel $(\mathrm{Y})$ adalah keputusan pembelian. Teknik pengumpulan data dengan mengunakan Populasi dan sampel. Teknik analisis yang digunakan dalam penelitian ini adalah dengan menggunakan alat bantu aplikasi SPSS Versi 22.

\section{HASIL dan PEMBAHASAN}

PT Tri Wahana Solusindo berdiri pada bulan September 2013 di Cengkareng, Jakarta barat. Bergerak dalam bidang manufaktur, distribusi dan penjualan perangkat dan kelengkapan per-parkiran yang mengcover seluruh wilayah Indonesia yang mengedepankan kualitas dan solusi terbaik dengan didukung sumber daya manusia yang kompeten, serta layanan purna jual yang terbaik adalah upaya dalam memberikan kepuasan bagi seluruh pelanggan Seiring dengan berkembangnya industri bisnis saat ini mengakibatkan beberapa perusahaan berorientasi pada permintaan pelanggan.

Responden dalam penelitian ini adalah para konsumen PT TRI WAHANA.Jumlah responden yang dijadikan sampel dalam penelitian ini sebanyak 83 responden. Karena semua responden adalah konsumen, maka untuk karakteristik responden ini terdiri dari jenis kelamin, usia dan Pendidikan terakhir.

Karakteristik dari masing-masing responden disajikan dalam tabel sebagai berikut:

Tabel 1.3. Data Responden Menurut Jenis Kelamin

\begin{tabular}{|c|c|c|c|c|c|}
\hline \multicolumn{6}{|c|}{ jenis kelamin } \\
\hline & & Frequency & Percent & Valid Percent & $\begin{array}{c}\text { Cumulative } \\
\text { Percent }\end{array}$ \\
\hline \multirow[t]{3}{*}{ Valid } & laki-laki & 34 & 41.0 & 41.0 & 41.0 \\
\hline & perempuan & 49 & 59.0 & 59.0 & 100.0 \\
\hline & Total & 83 & 100.0 & 100.0 & \\
\hline
\end{tabular}

Berdasarkan tabel di atas dapat dilihat bahwa hampir sebagian besar responden berjenis kelamin perempuan yaitu 49 orang (59.0\%), dan responden berjenis kelamin laki-laki yaitu 34 orang (41.0\%) dengan total jumlah responden 83 (100\%).

Tabel 1.4. Data Responden Menurut Umur

\begin{tabular}{|c|c|c|c|c|c|}
\hline \multicolumn{6}{|c|}{ umur } \\
\hline & & Frequency & Percent & Valid Percent & $\begin{array}{c}\text { Cumulative } \\
\text { Percent }\end{array}$ \\
\hline \multirow[t]{4}{*}{ Valid } & $21-30$ & 47 & 56.6 & 56.6 & 56.6 \\
\hline & $31-40$ & 25 & 30.1 & 30.1 & 86.7 \\
\hline & $41-50$ & 11 & 13.3 & 13.3 & 100.0 \\
\hline & Total & 83 & 100.0 & 100.0 & \\
\hline
\end{tabular}


Berdasarkan tabel di atas dapat dilihat bahwa hampir sebagian besar responden berumur antara 21-30 tahun, dengan jumlah responden sebanyak 47 orang (56.6\%), lalu responden dengan umur 31 - 40 sebanyak 25 orang (30.1\%) dan terakhir responden dengan umur 41 - 50 sebanyak 11 orang (13.3\%) dengan total jumlah responden 98 (100\%).

\begin{tabular}{|c|c|c|c|c|c|}
\hline \multicolumn{6}{|c|}{$\begin{array}{c}\text { Tabel 1.5. Data Responden Menurut } \\
\text { Pendidikan Terakhir }\end{array}$} \\
\hline \multicolumn{6}{|c|}{ pendidikan terakhir } \\
\hline & & Frequency & Percent & Valid Percent & $\begin{array}{c}\text { Cumulative } \\
\text { Percent }\end{array}$ \\
\hline \multirow[t]{5}{*}{ Valid } & sma & 38 & 45.8 & 45.8 & 45.8 \\
\hline & D3 & 8 & 9.6 & 9.6 & 55.4 \\
\hline & s1 & 26 & 31.3 & 31.3 & 86.7 \\
\hline & s2 & 11 & 13.3 & 13.3 & 100.0 \\
\hline & Total & 83 & 100.0 & 100.0 & \\
\hline
\end{tabular}

Berdasarkan tabel di atas dapat dilihat bahwa rata-rata pendidikan terakhir responden adalah SMA atau sederajat yaitu sebanyak 38 orang (45.8\%) kemudian responden dengan pendidikan terakhir D3 sebanyak 8 orang (9.6\%), responden pendidikan terakhir responden S1 sebanyak 26 orang (31.3\%), pendidikan terakhir S2 sebanyak 11 orang (13.3\%) dengan total jumlah responden 98 (100\%).

\section{Hasil}

\section{Uji Validitas}

Dalam mengolah uji validitas tiap butir pertanyaan dilakukan dengan membandingkan $r_{\text {hitung }}$ dengan $r_{\text {tabel }}$. Taraf signifikansi $\alpha=0,05$ (5\%) dengan tingkat kepercayaan pengujian 95\%. Kriteria ketentuan keputusan validitas sebagai berikut: a. Jika $r_{\text {hitung }}>r_{\text {tabel }}$ maka dikatakan Valid

b. Jika $r_{\text {hitung }}<r_{\text {tabel }}$ maka dikatakan Tidak

\section{Valid}

Tabel 1.6. Hasil Uji Validitas Instrumen Pernyataan Kualitas Produk $\left(X_{1}\right)$

\begin{tabular}{|c|c|c|c|c|}
\hline No & Pernyataan & $\begin{array}{l}\mathbf{r} \\
\text { hitung }\end{array}$ & $\stackrel{\mathbf{r}}{\text { tabel }} 5 \%$ & Kriteria \\
\hline \multicolumn{5}{|c|}{ Kinerja (performance) } \\
\hline 1. & $\begin{array}{lr}\text { Produk perangkat parkir } \\
\text { PT. Tri } & \text { Wahana } \\
\text { Solusindo } & \text { berkualitas } \\
\text { tinggi } & \\
\end{array}$ & 0,547 & 0,215 & Valid \\
\hline 2. & $\begin{array}{l}\text { Produk perangkat parkir } \\
\text { PT. Tri Wahana Solu } \\
\text { sindo memiliki kesesuai } \\
\text { an kinerja dengan } \\
\text { standar yang dinyatakan } \\
\text { suatu produk }\end{array}$ & 0,686 & 0,215 & Valid \\
\hline \multicolumn{5}{|c|}{ Ciri-ciri tambahan (Features) } \\
\hline 3 & $\begin{array}{l}\text { Produk perangkat parkir } \\
\text { menyediakan berbagai } \\
\text { macam fitur layanan } \\
\text { yang sesuai dengan } \\
\text { kebutuhan saya }\end{array}$ & 0,464 & 0,215 & Valid \\
\hline 4. & $\begin{array}{l}\text { Produk perangkat parkir } \\
\text { menyediakan fitur-fitur } \\
\text { yang lengkap dan } \\
\text { canggih }\end{array}$ & 0,686 & 0,215 & Valid \\
\hline \multicolumn{5}{|c|}{$\begin{array}{l}\text { Kesesuaian dengan Spesifikasi (Conformance to } \\
\text { specification }\end{array}$} \\
\hline 5 & $\begin{array}{l}\text { Produk perangkat parkir } \\
\text { PT Tri Wahana } \\
\text { Solusindo sesuai dengan } \\
\text { standart dan kualitas } \\
\text { yang ditawarkan }\end{array}$ & 0,481 & 0,215 & Valid \\
\hline 6. & $\begin{array}{l}\text { Produkperangkat parkir } \\
\text { PT Tri Wahana Solu } \\
\text { sindo memberi manfaat } \\
\text { fungsional }\end{array}$ & 0,218 & 0,215 & Valid \\
\hline \multicolumn{5}{|c|}{ Keandalan (Realibility) } \\
\hline $7 \cdot$ & $\begin{array}{l}\text { Produkperangkat parkir } \\
\text { PT Tri Wahana Solu } \\
\text { sindo merupakan } \\
\text { perangkat parkir yang } \\
\text { memiliki material yang } \\
\text { tahan lama }\end{array}$ & 0,563 & 0,215 & Valid \\
\hline 8. & $\begin{array}{l}\text { Produkperangkat parkir } \\
\text { PT Tri Wahana Solu } \\
\text { sindo semakin meng- } \\
\text { ikuti perkembangan } \\
\text { teknologi terbaru }\end{array}$ & 0,686 & 0,215 & Valid \\
\hline \multicolumn{5}{|c|}{ Daya tahan (Durability) } \\
\hline 9. & $\begin{array}{l}\text { Produkperangkat parkir } \\
\text { PT Tri Wahana Solu } \\
\text { sindo memiliki kualitas } \\
\text { yang tahan lama }\end{array}$ & 0,521 & 0,215 & Valid \\
\hline 10 & $\begin{array}{l}\text { Produkperangkat parkir } \\
\text { PT Tri Wahana Solu } \\
\text { sindo memiliki body } \\
\text { yang tahan banting }\end{array}$ & 0,420 & 0,215 & Valid \\
\hline \multicolumn{5}{|c|}{ Estetika (Easthetica) } \\
\hline 11. & $\begin{array}{l}\text { Produkperangkat parkir } \\
\text { PT Tri Wahana Solu } \\
\text { sindo memiliki tampilan } \\
\text { fisik yang mengesankan }\end{array}$ & 0,547 & 0,215 & Valid \\
\hline
\end{tabular}




\begin{tabular}{|c|l|c|c|c|}
\hline No & \multicolumn{1}{|c|}{ Pernyataan } & $\begin{array}{c}\mathbf{r} \\
\text { hitung }\end{array}$ & $\begin{array}{c}\mathbf{r} \\
\text { tabel 5\% }\end{array}$ & Kriteria \\
\hline 12. & $\begin{array}{l}\text { Produk perangkat parkir } \\
\begin{array}{l}\text { PT Tri Wahana Solu } \\
\text { sindo memiliki kemasan } \\
\text { yang menarik }\end{array}\end{array}$ & $\mathbf{0 , 5 6 3}$ & $\mathbf{0 , 2 1 5}$ & Valid \\
\hline
\end{tabular}

Dari tabel di atas semua pernyataan variabel kualitas produk $\left(\mathrm{X}_{1}\right)$ dinyatakan valid karena nilai $r_{\text {hitung }}$ lebih besar dari nilai $r_{\text {tabel }}$.

\begin{tabular}{|c|c|c|c|c|}
\hline \multicolumn{5}{|c|}{$\begin{array}{l}\text { Tabel 1.7. Hasil Uji Validitas Instrumen } \\
\text { Pernyataan Strategi Pemasaran }\left(X_{2}\right)\end{array}$} \\
\hline No & Pernyataan & \begin{tabular}{|c|}
$\mathrm{r}$ \\
hitung
\end{tabular} & \begin{tabular}{|c}
$\mathrm{r}$ tabel \\
$5 \%$
\end{tabular} & Kriteria \\
\hline \multicolumn{5}{|c|}{ Pengenalan Masalah } \\
\hline 1. & $\begin{array}{l}\text { Produk Perangkat } \\
\text { parkir menawarkan } \\
\text { memperluas distribusi } \\
\text { pada website dan media } \\
\text { online }\end{array}$ & 0,483 & 0,215 & Valid \\
\hline 2. & $\begin{array}{l}\text { Produk Perangkat } \\
\text { Parkir menawarkan } \\
\text { strategi pemasaran } \\
\text { dengan mengadakan } \\
\text { pameran atau event }\end{array}$ & 0,428 & 0,215 & Valid \\
\hline \multicolumn{5}{|c|}{ Memperluas lini produk } \\
\hline 3. & $\begin{array}{l}\text { Kualitas produk } \\
\text { Perangkat Parkir lebih } \\
\text { di tingkatkan }\end{array}$ & 0,379 & 0,215 & Valid \\
\hline 4. & $\begin{array}{l}\text { Menganalisa pangsa } \\
\text { pasar Perangkat Parkir }\end{array}$ & 0,428 & 0,215 & Valid \\
\hline \multicolumn{5}{|c|}{ Merebut pelanggan pesaing } \\
\hline 5. & $\begin{array}{l}\text { Meningkatkan kualitas } \\
\text { produk Perangkat } \\
\text { Parkir }\end{array}$ & 0,670 & 0,215 & Valid \\
\hline 6. & $\begin{array}{l}\text { Meningkatkan mutu dan } \\
\text { pelayanan Perangkat } \\
\text { Parkir }\end{array}$ & 0,354 & 0,215 & Valid \\
\hline \multicolumn{5}{|c|}{ Mempertahankan dan meningkatkan permintaan pelanggan } \\
\hline 7. & $\begin{array}{l}\text { Melakukan inovasi } \\
\text { Perangkat Parkir dan } \\
\text { mengupdate sesuai } \\
\text { dengan teknologi terkini }\end{array}$ & 0,670 & 0,215 & Valid \\
\hline 8. & $\begin{array}{l}\text { Memberikan } \\
\text { komunikasi Perangkat } \\
\text { Parkir } \\
\text { sesuai dengan kegunaan } \\
\text { dan manfaat yang } \\
\text { dirasakan. }\end{array}$ & 0,298 & 0,215 & Valid \\
\hline \multicolumn{5}{|c|}{ Mempertahankan tingkat kepuasan pelangan } \\
\hline 9. & $\begin{array}{l}\text { Memberikan pelayan } \\
\text { prima }\end{array}$ & 0,369 & 0,215 & Valid \\
\hline 10 & $\begin{array}{l}\text { Berkomitmen dengan } \\
\text { pelanggan }\end{array}$ & 0,379 & 0,215 & Valid \\
\hline \multicolumn{5}{|c|}{ Menjalin marketing relationship } \\
\hline 11. & $\begin{array}{l}\text { Memberikan informasi } \\
\text { berkala Perangkat } \\
\text { Parkir }\end{array}$ & 0,369 & 0,215 & Valid \\
\hline 12. & $\begin{array}{l}\text { Saling berkomitmen } \\
\text { tinggi Produk Perangkat } \\
\text { Parkir }\end{array}$ & 0,359 & 0,215 & Valid \\
\hline
\end{tabular}

Dari tabel di atas semua pernyataan variabel strategi pemasaran $\left(\mathrm{X}_{2}\right)$ dinyatakan valid karena nilai $r_{\text {hitung }}$ lebih besar dari nilai $r_{\text {tabel }}$

\section{Tabel 1.8. Hasil Uji Validitas Instrumen} Keputuan Pembelian (Y)

\begin{tabular}{|c|c|c|c|c|}
\hline No & Pernyataan & $\begin{array}{l}\text { r } \\
\text { hitung }\end{array}$ & $\begin{array}{c}\mathbf{r} \text { tabel } \\
5 \%\end{array}$ & Kriteria \\
\hline \multicolumn{5}{|c|}{ Pengenalan masalah } \\
\hline 1. & $\begin{array}{l}\text { Saya menyadari } \\
\text { kebutuhan akan } \\
\text { perangkat parkir PT. Tri } \\
\text { Wahana Solusindo } \\
\end{array}$ & 0,707 & 0,215 & Valid \\
\hline 2. & $\begin{array}{l}\text { Saya memakai } \\
\text { perangkat parkir PT. Tri } \\
\text { Wahana Solusindo } \\
\text { karena dapat memenuhi } \\
\text { kebutuhan perusahaan }\end{array}$ & 0,301 & 0,215 & Valid \\
\hline \multicolumn{5}{|c|}{ Pencarian informasi } \\
\hline 3. & $\begin{array}{l}\text { Saya melakukan } \\
\text { pencarian informasi } \\
\text { tentang perangkat } \\
\text { parkir PT. Tri Wahana } \\
\text { Solusindo }\end{array}$ & 0,334 & 0,215 & Valid \\
\hline 4. & $\begin{array}{l}\text { Saya tidak mendapatkan } \\
\text { hambatan dalam } \\
\text { melakukan pencarian } \\
\text { informasi tentang } \\
\text { perangkat parkir PT. Tri } \\
\text { Wahana Solusindo }\end{array}$ & 0,590 & 0,215 & Valid \\
\hline
\end{tabular}

\section{Evaluasi alternative}

\begin{tabular}{|c|c|c|c|c|}
\hline 5. & $\begin{array}{l}\text { Saya melakukan evaluasi } \\
\text { dari berbagai informasi } \\
\text { yang diterima }\end{array}$ & 0,707 & 0,215 & Valid \\
\hline 6. & $\begin{array}{l}\text { Menurut saya perangkat } \\
\text { parkir PT. Tri Wahana } \\
\text { Solusindo memiliki } \\
\text { prestise yang baik }\end{array}$ & 0,268 & 0,215 & Valid \\
\hline
\end{tabular}

\section{Keputusan pembelian}

\begin{tabular}{|c|c|c|c|c|}
\hline 7. & $\begin{array}{l}\text { Saya memutuskan } \\
\text { membeli perangkat } \\
\text { parkir PT. Tri Wahana } \\
\text { Solusindo karena } \\
\text { memiliki garansi resmi }\end{array}$ & 0,611 & 0,215 & Valid \\
\hline 8. & $\begin{array}{l}\text { Saya membeli perangkat } \\
\text { parkir PT. Tri Wahana } \\
\text { Solusindo karena } \\
\text { berkualitas }\end{array}$ & 0,734 & 0,215 & Valid \\
\hline \multicolumn{5}{|c|}{ Perilaku pasca pembelian } \\
\hline 9. & $\begin{array}{l}\text { Saya merasa puas } \\
\text { terhadap perangkat } \\
\text { parkir PT. Tri Wahana } \\
\text { Solusindo sehingga ada } \\
\text { keinginan untuk } \\
\text { membeli kembali di lain } \\
\text { waktu }\end{array}$ & 0,535 & 0,215 & Valid \\
\hline $\begin{array}{l}10 \\
.\end{array}$ & $\begin{array}{l}\text { Saya akan } \\
\text { merekomendasikan } \\
\text { perangkat parkir PT. Tri } \\
\text { Wahana Solusindo } \\
\text { kepada perusahaan lain }\end{array}$ & 0,595 & 0,215 & Valid \\
\hline
\end{tabular}

Dari tabel di atas semua pernyataan variabel keputusan pembelian (Y) dinyatakan valid 
karena nilai $r_{\text {hitung }}$ lebih besar dari nilai $r_{\text {tabel }}$

\section{Hasil Uji Reliabilitas}

Dalam mengolah uji reliabilitas tiap butir pertanyaan dilakukan dengan membandingkan antara nilai Chronbach Alpha dengan standar Chronbach Alpha 0,60 menurut Ghozali (2013:238). Taraf signifikansi $\alpha=$ 0,05 (5\%) dengan tingkat kepercayaan pengujian 95\%. Kriteria ketentuan keputusan validitas sebagai berikut :

1) Jika Chronbach Alpha> o,6o maka dikatakan Reliabel

2) Jika Chronbach Alpha < 0,60 maka dikatakan Tidak Reliabel.

\section{Tabel 1.9. Hasil Uji Reliabilitas Instrumen}

\begin{tabular}{|l|c|c|c|}
\hline \multicolumn{1}{|c|}{ Variabel } & $\begin{array}{c}\text { Chronbac } \\
\text { h Alpha }\end{array}$ & $\begin{array}{c}\text { Standar } \\
\text { Chrombach } \\
\text { Alpha }\end{array}$ & Kriteria \\
\hline $\begin{array}{l}\text { Kualitas } \\
\text { Produk (X) }\end{array}$ & 0,769 & 0,60 & Reliabel \\
\hline $\begin{array}{l}\text { Strategi } \\
\text { Pemasaran } \\
\left(\mathrm{X}_{2}\right)\end{array}$ & 0,629 & 0,60 & Reliabel \\
\hline $\begin{array}{l}\text { Keputusan } \\
\text { pembelian (Y) }\end{array}$ & 0,697 & 0,60 & Reliabel \\
\hline
\end{tabular}

Dari tabel diatas hasil uji reliabilitas diperoleh nilai Chronbach Alpha semua variabel lebih besar dari nilai Standar Chronbach Alpha yaitu 0,6o, disimpulkan bahwa semua angket dalam penelitian ini reliabel atau konsisten.

\section{Pengujian Asumsi Klasik}

\section{Hasil Uji Normalitas}

Uji normalitas dilakukan untuk menguji apakah dalam model regresi variabel bebas dan variabel terikat berdistribusi normal atau tidak. Uji normalitas residual variabel dapat diketahui dengan melihat penyebaran titiktitik residual mengikuti arah garis diagonal.

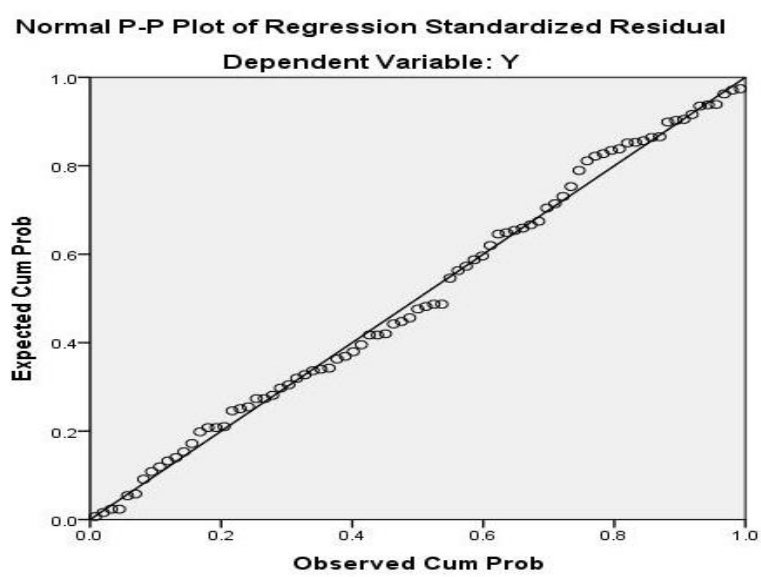

Gambar 4.2 Hasil Uji P-Plot Uji Normalitas

Pada gambar grafik normal probability plot menunjukkan pola grafik yang normal dengan dibuktikan adanya titik yang menyebar disekitar garis diagonal mengikuti garis diagonal.Dari gambar diatas dapat disimpulkan model regresi memenuhi asumsi normalitas.

\section{Hasil Uji Multikolinearitas}

Pengujian ultikolinearitas dilakukan untuk menyakini bahwa antar variabel bebas tidak memiliki multikolinearitas atau tidak memiliki hubungan korelasi antara variabel yang ditetapkan karena model regresi yang baik seharusnya tidak terjadi korelasi di antara variabel bebas.Uji multikolinearitas dapat dilakukan dengan melihat nilai Tolerance Value dan Variance Inflation Factor (VIF). Adapun kriterianya adalah sebagai berikut: 
a) Jika nilai VIF $<10$ dan nilai Tolerance value $>1$ maka terjadi multikolinearitas

b) Jika nilai VIF > 10 dan nilai Tolerance value $<1$ maka tidak terjadi multikolinearitas.

Adapun Hasil dari uji multikolinearitas sebagai berikut:

Tabel 1.10. Hasil Uji Multikolinearitas Collinearity Statistic

\begin{tabular}{|c|c|c|c|c|c|c|c|c|}
\hline \multicolumn{9}{|c|}{ Coefficients $^{\mathrm{a}}$} \\
\hline \multirow[b]{2}{*}{ Mode } & & \multicolumn{2}{|c|}{ Unstandardized Coefficients } & $\begin{array}{c}\text { Standardized } \\
\text { Coefficients }\end{array}$ & \multirow[b]{2}{*}{$t$} & \multirow[b]{2}{*}{ Sig. } & \multicolumn{2}{|c|}{ Collinearity Statistics } \\
\hline & & B & Std. Error & Beta & & & \begin{tabular}{|l} 
Tolerance \\
\end{tabular} & VIF \\
\hline \multirow[t]{3}{*}{1} & (Constant) & 3.573 & 4.084 & & .875 & .384 & & \\
\hline & $\mathrm{x} 1$ & .474 & .090 & .507 & 5.278 & .000 & .644 & 1.553 \\
\hline & $\mathrm{X} 2$ & .280 & .087 & .308 & 3.208 & .002 & .644 & 1.553 \\
\hline
\end{tabular}

Berdasarkan tabel diatas dapat diperoleh nilai Tolerance masing-masing variabel bebas yaitu kualitas produk $\left(\mathrm{X}_{1}\right)$ 0,644 dan Strategi Pemasaran $\left(\mathrm{X}_{2}\right)$ o,644 dimana nilai tersebut kurang dari 1, sedangkan nilai Variance Inflation Factor (VIF) untuk kualitas produk $\left(\mathrm{X}_{1}\right)$ 1,553 dan Strategi Pemasaran $\left(\mathrm{X}_{2}\right)$ 1,553 yang dimana dapat dikatakan nilai tersebut kurang dari 10 dengan demikian model regresi ini tidak terjadi multikolinearitas.

\section{Hasil Uji Heterokedastisitas}

Pengujian heterokedastisitas dilakukan untuk menguji apakah dalam sebuah model regresi terjadi ketidaksamaan variance residual. Salah satu cara untuk mendeteksi ada tidaknya heterokedastisitas adalah dengan melihaat grafik scatter plot antara nilai prediksi variabel terikat (ZPRED) dan nilai residualnya (SRESID) dengan kriteria sebagai berikut : a) Jika ada titik-titik yang membentuk pola tertentu yang teratur seperti bergelombang, melebar kemudian menyempit, maka mengiindikasikan adanya heterokedastisitas.

b) Jika tidak terdapat pola tertentu yang jelas, serta titik-titik menyebar diatas dan dibawah angka nol pada sumbu Y maka mengindikasikan tidak terjadi heteroskedastisitas.

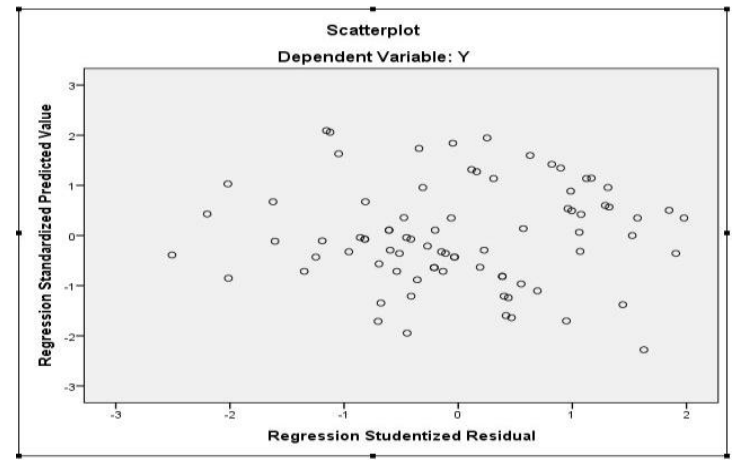

Gambar 4.3 Hasil Uji Heterokedastisitas dengan Scatter Plot

Berdasarkan gambar di atas, titik-titik pada gambar Scatter Plot tidak mempunyai pola penyebaran yang jelas atau tidak membentuk pola-pola tertentu.Titi-titik tersebut menyebar di atas dan di bawah angka o pada sumbu Y, maka hal ini menunjukkan bahwa tidak terjadi heterokedastisitas pada model regresi sehingga model regresi ini layak digunakan.

\section{Hasil Uji Regresi Linier Sederhana}

\begin{tabular}{|c|c|c|c|c|c|}
\hline \multicolumn{6}{|c|}{$\begin{array}{c}\text { Tabel 1.11 Hasil Uji Regresi } \\
\text { Linier Sederhana } X_{1}\end{array}$} \\
\hline \multicolumn{6}{|c|}{ Coefficients $^{a}$} \\
\hline \multirow[b]{2}{*}{ Model } & \multicolumn{2}{|c|}{ Unstandardized Coefficients } & \multirow{2}{*}{$\begin{array}{c}\begin{array}{c}\text { Standardized } \\
\text { Coefficients }\end{array} \\
\text { Beta }\end{array}$} & \multirow[b]{2}{*}{$\mathrm{t}$} & \multirow[b]{2}{*}{ Sig. } \\
\hline & $\mathrm{B}$ & Std. Error & & & \\
\hline (Constant) & 9.024 & 3.926 & & 2.298 & .024 \\
\hline $\mathrm{X}_{1}$ & .646 & .076 & .690 & 8.479 & .000 \\
\hline
\end{tabular}


Berdasarkan hasil di atas pada tabel confficients diketahui nilai t sebesar 8.479 dengan nilai sig. sebesar 0.000 yang berarti nilai tersebut < 0,05 maka dapat disimpulkan Ho ditolak dan Ha diterima, artinya ada pengaruh yang signifikan antara kualitas produk terhadap keputusan pembelian. Dan diperoleh persamaan regresinya sebagai berikut: $Y=9,024+0,646 X_{1}$

\begin{tabular}{|c|c|c|c|c|c|}
\hline \multicolumn{6}{|c|}{$\begin{array}{c}\text { Table 1.12 Hasil Uji Regresi Linier } \\
\text { Sederhana } \mathrm{X}_{2}\end{array}$} \\
\hline \multicolumn{6}{|c|}{ Coefficients $^{\mathrm{a}}$} \\
\hline \multirow[b]{2}{*}{ Model } & \multicolumn{2}{|c|}{ Unstandardized Coefficients } & $\begin{array}{l}\text { Standardized } \\
\text { Coefficients }\end{array}$ & \multirow[b]{2}{*}{$t$} & \multirow[b]{2}{*}{ Sig. } \\
\hline & $\mathrm{B}$ & Std. Error & Beta & & \\
\hline $\begin{array}{ll}1 & \text { (Constant) } \\
\end{array}$ & 13.907 & 4.149 & & 3.351 & .001 \\
\hline$x_{2}$ & .555 & .081 & .610 & 6.844 & .000 \\
\hline
\end{tabular}

Berdasarkan hasil di atas pada tabel confficients diketahui nilai t sebesar 6.844 dengan nilai sig. sebesar 0.000 yang berarti nilai tersebut < 0,05 maka dapat disimpulkan Ho ditolak dan Ha diterima, artinya ada pengaruh yang signifikan antara harga terhadap keputusan pembelian. Dan diperoleh persamaan regresinya sebagai berikut: $\mathrm{Y}=13,907+0,555 \mathrm{X}_{2}$

\section{Hasil Uji Regresi Linier Berganda}

Analisis regresi digunakan untuk melakukan prediksi bagaimana perubahan nilai variabel terikat bila nilai variabel bebas dinaikkan atau diturunkan (Sugiyono, 2014:277).

Tabel 1.13 Hasil Uji Regresi Linier Berganda

\begin{tabular}{|c|c|c|c|c|c|c|c|c|}
\hline \multicolumn{9}{|c|}{ Coefficients $^{a}$} \\
\hline & & \multicolumn{2}{|c|}{ Unstandardized Coefficients } & $\begin{array}{l}\text { Standardized } \\
\text { Coefficients }\end{array}$ & \multirow[b]{2}{*}{$t$} & \multirow[b]{2}{*}{ Sig. } & \multicolumn{2}{|c|}{ Collinearity Statistics } \\
\hline \multicolumn{2}{|c|}{ Model } & $B$ & Std. Error & Beta & & & \begin{tabular}{|l} 
Tolerance \\
\end{tabular} & VIF \\
\hline & (Constant) & 3.573 & 4.084 & & .875 & .384 & & \\
\hline & $\mathrm{x}_{1}$ & .474 & .090 & .507 & 5.278 & .000 & .644 & 1.553 \\
\hline & $\mathrm{X}_{2}$ & .280 & .087 & .308 & 3.208 & .002 & .644 & 1.553 \\
\hline
\end{tabular}

Berdasarkan tabel di atas diperoleh persamaan regresi $\mathrm{Y}=3.573+0.474 \mathrm{X}_{1}+$ $0.280 \mathrm{X}_{2}$,.

1. Konstanta sebesar 3,574 menyatakan bahwa tanpa ada variabel kualitas produk $\left(\mathrm{X}_{1}\right)$ dan strategi pemasaran $\left(\mathrm{X}_{2}\right)$ maka keputusan pembelian (Y) tetap terbentuk sebesar 3,574 atau jika nilai kualitas produk $\left(\mathrm{X}_{1}\right)$ dan strategi pemasaran $\left(\mathrm{X}_{2}\right)$ nilainya $=0$ maka keputusan pembelian (Y) tetap memiliki nilai $=3,574$. Yang artinya konsumen akan tetap datang untuk membeli produk meskipun kualitas produk dan strategi pemasarannya yang diberikan masih kurang.

2. Nilai variabel kualitas produk $\left(\mathrm{X}_{1}\right)$ sebesar 0,474, apabila tetap dan tidak ada perubahan pada variabel kualitas produk $\left(\mathrm{X}_{1}\right)$, maka setiap perubahan 1 unit pada variabel kualitas produk $\left(\mathrm{X}_{1}\right)$ akan mengakibatkan perubahan pada (Y) sebesar 0,474.

3. Nilai variabel strategi pemasaran $\left(X_{2}\right)$ sebesar 0,280, diartikan apabila tetap dan tidak ada perubahan pada variabel harga $\left(\mathrm{X}_{2}\right)$, maka setiap perubahan 1 unit pada variabel strategi pemasaran $\left(\mathrm{X}_{2}\right)$ akan mengakibatkan terjadinyaa perubahan pada (Y) sebesar 0,280.

\section{Hasil Uji Koefisien Determinasi}

Analisis koefisien determinasi (Kd) digunakan untuk mengetahui seberapa besar persentase kontribusi pengaruh antara variabel kualitas produk $\left(\mathrm{X}_{1}\right)$ dan strategi 
pemasaran $\left(\mathrm{X}_{2}\right)$ baik secara parsial maupun secara simultan terhadap variabel keputusan pembelian (Y). Adapun cara untuk mengetahui hubungan tersebut dapat digunakan rumus $K D=r^{2} \times 100 \%$ yang diolah dengan program Statistical Product and Service Solution (SPSS) versi 22, sebagai berikut :

Tabel 1.14 Hasil Uji Koefisien Determinasi

\begin{tabular}{|l|c|r|r|r|r|}
\hline \multicolumn{7}{|c|}{ Model Summary $^{\mathrm{b}}$} \\
\hline Model & $\mathrm{R}$ & R Square & $\begin{array}{c}\text { Adjusted R } \\
\text { Square }\end{array}$ & $\begin{array}{l}\text { Std. Error of } \\
\text { the Estimate }\end{array}$ & $\begin{array}{c}\text { Durbin- } \\
\text { Watson }\end{array}$ \\
\hline 1 & $.733^{\mathrm{a}}$ & .537 & .526 & 2.49528 & 2.609 \\
\hline
\end{tabular}

Berdasarkan hasil pada tabel diatas dapat diperoleh nilai $\mathrm{R}$ Square sebesar o,537. Oleh karena uji koefisien determinasi berganda ini diperoleh dari perhitungan regresi linear berganda, maka koefisien determinasi sebesar 0,537 atau $\mathrm{R}^{2}$ x 100\% adalah sebesar 53,7\%. Hal tersebut menunjukan bahwa variabel kualitas produk $\left(\mathrm{X}_{1}\right)$ dan strategi pemasaran $\left(\mathrm{X}_{2}\right)$ berpengaruh terhadap keputusan pembelian sebesar 53,7\% dan sisanya 46,3\% dipengaruhi oleh variabel-variabel lain diluar dari penelitian ini.

\section{Uji Koefisien Korelasi}

Untuk mengetahui hubungan variabel kualitas produk $\left(\mathrm{X}_{1}\right)$ dan strategi pemasaran $\left(\mathrm{X}_{2}\right)$ terhadap keputusan pembelian (Y) secara parsial maka digunakan analisis koefisien korelasi. Adapun hasil persentase tingkat hubungan secara parsial sebagai berikut:

\begin{tabular}{|c|c|c|c|c|}
\hline \multicolumn{5}{|c|}{$\begin{array}{c}\text { Tabel 1.15 Hasil Uji } \\
\text { Koefisien Korelasi Kualitas Produk }\left(X_{1}\right) \\
\text { terhadap Keputusan Pembelian }(Y)\end{array}$} \\
\hline \multicolumn{5}{|c|}{ Model Summary ${ }^{b}$} \\
\hline Model & $\mathrm{R}$ & R Square & $\begin{array}{c}\text { Adjusted R } \\
\text { Square }\end{array}$ & $\begin{array}{l}\text { Std. Error of } \\
\text { the Estimate }\end{array}$ \\
\hline 1 & $.690^{\mathrm{a}}$ & $\begin{array}{r}476 \\
\end{array}$ & .470 & 2.63790 \\
\hline \multicolumn{5}{|c|}{ a. Predictors: (Constant), $\times 1$} \\
\hline & & & & \\
\hline
\end{tabular}

Nilai koefisien korelasi sebesar 0,690 karena terletak antara 0,600-0,799 berarti variabel kualitas produk memiliki hubungan yang kuat terhadap variable keputusan pembelian.

\begin{tabular}{|c|c|c|c|c|}
\hline \multicolumn{5}{|c|}{$\begin{array}{c}\text { Tabel 1.16 Hasil Uji } \\
\text { Koefisien Korelasi Strategi Pemasaran } \\
\left(\mathrm{X}_{2}\right) \text { Terhadap Keputusan Pembelian (Y) }\end{array}$} \\
\hline \multicolumn{5}{|c|}{ Model Summary ${ }^{b}$} \\
\hline Model & $\mathrm{R}$ & $\mathrm{R}$ Square & $\begin{array}{l}\text { Adjusted R } \\
\text { Square }\end{array}$ & $\begin{array}{l}\text { Std. Error of } \\
\text { the Estimate }\end{array}$ \\
\hline 1 & $.610^{\mathrm{a}}$ & .372 & .364 & 2.88851 \\
\hline \multicolumn{5}{|c|}{ a. Predictors: (Constant), $\times 2$} \\
\hline
\end{tabular}

Nilai koefisien korelasi sebesar 0,610 karena terletak antara 0,600-0,799 berarti variabel strategi pemasaran memiliki hubungan yang kuat terhadap variable keputusan pembelian.

\section{Uji Hipotesis}

\section{Hasil Uji t (parsial)}

Pada penelitian ini pengujian hipotesis kualitas produk $\left(\mathrm{X}_{1}\right)$ dan strategi pemasaran $\left(\mathrm{X}_{2}\right)$ terhadap keputusan pembelian (Y) dengan uji statistic t secara parsial dengan kriteria signifikan $5 \%$ dengan membandingkan $t_{\text {hitung }}$ dengan $t_{\text {tabel }}$ sebagai berikut :

1) Jika $t_{\text {hitung }}>t_{\text {tabel }}$ maka terdapat pengaruh secara parsial antara variabel Kualitas Produk $\left(\mathrm{X}_{1}\right)$ atau strategi 
pemasaran $\left(\mathrm{X}_{2}\right)$ terhadap Keputusan Pembelian (Y)

2) Jika $t_{\text {hitung }}<t_{\text {tabel }}$ maka tidak terdapat pengaruh secara parsial antara variabel Kualitas Produk $\left(\mathrm{X}_{1}\right)$ atau strategi pemasaran $\left(\mathrm{X}_{2}\right)$ terhadap Keputusan Pembelian (Y)

\begin{tabular}{|c|c|c|c|c|c|c|c|}
\hline $\begin{array}{l}\text { Variab } \\
\left(X_{2}\right) \text { te }\end{array}$ & $\begin{array}{l}\text { Ta } \\
\text { thada }\end{array}$ & $\begin{array}{l}\text { bel } 1 . \\
\text { litas } \\
\text { p Kel }\end{array}$ & $\begin{array}{l}7 \mathrm{Ha} \\
\text { Produ } \\
\text { utusa }\end{array}$ & $\begin{array}{l}1 \mathrm{U} \\
\mathrm{OX} \\
\mathrm{Pe}\end{array}$ & d $\mathrm{d}$ & $\begin{array}{l}\mathbf{n} \mathrm{Ha} \\
\text { lian }\end{array}$ & $\begin{array}{l}\text { rga } \\
\text { (Y) }\end{array}$ \\
\hline & & & efficients ${ }^{a}$ & & & & \\
\hline & Unstandardiz & Coefficients & $\begin{array}{l}\text { Standardized } \\
\text { Coefficients }\end{array}$ & & & Collinearity & atistics \\
\hline Model & $B$ & Std. Error & Beta & t & Sig. & Tolerance & VIF \\
\hline $1 \quad$ (Constant) & 3.573 & 4.084 & & .875 & .384 & & \\
\hline$x_{1}$ & .474 & .090 & .507 & 5.278 & .000 & .644 & 1.553 \\
\hline$x_{2}$ & .280 & .087 & .308 & 3.208 & .002 & .644 & 1.553 \\
\hline
\end{tabular}

Berdasarkan tabel diatas dapat disimpulkan bahwa:

1. Ho1 = Pengaruh kualitas produk terhadap keputusan pembelian.Kualitas $\operatorname{produk}\left(\mathrm{X}_{1}\right)$ secara parsial berpengaruh terhadap keputusan pembelian (Y). Hal ini terlihat dari nilai $t_{\text {hitung }}>t_{\text {tabel }}(5,278>1,663)$ dan nilai signifikansi sebesar 0,000 < 0,05, sehingga Ha1 diterima, Ho1 ditolak.

2. $\mathrm{Ho2}=$ Pengaruh strategi pemasaran terhadap keputusan pembelian. Strategi pemasaran $\left(\mathrm{X}_{2}\right)$ secara parsial berpengaruh terhadap keputusan pembelian. Hal ini terlihat dari nilai $t_{\text {hitung }}>t_{\text {tabel }}$ $(3,208>$ 1,663) dan nilai signifikansi sebesar 0,002 < 0,05, sehingga $\mathrm{Ha} 2$ diterima dan Ho2 ditolak.

\section{Hasil Uji f (simultan)}

Uji simultan (Uji F) dilakukan untuk menguji seberapa signifikan pengaruh variabel $X_{1}$ dan $X_{2}$ secara bersama sama (simultan) terhadap variabel Y. Adapun hasil yang uji F di dapatkan hasil sebagai berikut:

Tabel 1.18 Hasil Uji f Variabel Kualitas

Produk $\left(X_{1}\right)$ dan strategi pemasaran $\left(X_{2}\right)$ terhadap Keputusan Pembelian (Y)

\begin{tabular}{|c|c|c|c|c|c|c|}
\hline \multicolumn{7}{|c|}{ ANOVA $^{a}$} \\
\hline \multicolumn{2}{|c|}{ Model } & $\begin{array}{l}\text { Sum of } \\
\text { Squares }\end{array}$ & df & Mean Square & $\mathrm{F}$ & Sig. \\
\hline \multirow[t]{3}{*}{1} & Regression & 564.338 & 2 & 282.169 & 45.318 & $.000^{\mathrm{b}}$ \\
\hline & Residual & 485.662 & 78 & 6.226 & & \\
\hline & Total & 1050.000 & 80 & & & \\
\hline \multicolumn{7}{|c|}{ a. Dependent Variable: $Y$} \\
\hline \multicolumn{7}{|c|}{ b. Predictors: (Constant), X2, X1 } \\
\hline
\end{tabular}

Berdasarkan tabel di atas terlihat $\mathrm{F}$ hitung $(45,318)>F$ tabel (3.11) dan nilai signifikansi (sig.) sebesar 0,000 < 0,05 dengan demikian Ho3 ditolak dan Ha3 diterima yang berarti kualitas produk dan strategi pemasaran secara bersama-sama (simultan) berpengaruh signifikan terhadap keputusan pembelian.

\section{Pembahasan}

1. Kualitas produk secara parsial berpengaruh terhadap keputusan pembelian pada PT Tri Wahana Solusindo dengan persamaan $\mathrm{Y}=9,024+0,646 \mathrm{X}_{1}$. Sedangkan hasil uji t diperoleh nilai thitung $>t_{\text {tabel }}(5,278>1,663)$ dengan nilai signifikansi 0,00<0,05.

2. Strategi pemasaran berpengaruh signifikan terhadap keputusan pembelian pada PT Tri Wahana Solusindo dengan persamaan $\mathrm{Y}=8,929+0,981 \mathrm{X}_{2}$. Sedangkan hasil uji parsial nilai $t_{\text {hitung }}$ $(3,208)>t_{\text {tabel }}(1,663)$ dan nilai signifikansi sebesar $0,002<0,05$. 
3. Secara simultan kualitas produk dan strategi pemasaran berpengaruh signifikan terhadap keputusan pembelian pada PT Tri Wahana Solusindo dengan persamaan regresi linier $\mathrm{Y}=3.573+$ $0.474 \mathrm{X}_{1}+0.280 \mathrm{X}_{2}$. Hasil uji F diperoleh nilai $\mathrm{F}_{\text {hitung }}(45,318)>\mathrm{F}_{\text {tabel }}(3.11)$ dan nilai signifikansi (sig.) sebesar $0,000<0,05$. Sedangkan konstribusi pengaruh kualitas produk dan strategi pemasaran terhadap keputusan pembelian sebesar 53,7\%.

\section{SIMPULAN}

\section{Kesimpulan}

1. Variabel kualitas produk secara parsial berpengaruh positif dan signifikan antara terhadap variabel keputusan pembelian, dengan hasil uji regresi linier sederhana $Y$ $=9,024+0,646 X_{1}$ dan hasil uji parsial $t_{\text {hitung }}>t_{\text {tabel }}(5,278>1,663)$.

2. Variabel strategi pemasaran secara parsial berpengaruh yang positif dan signifikan terhadap keputusan pembelian dengan hasil uji regresi linier sederhana $\mathrm{Y}=8,929$ $+0,981 \mathrm{X}_{2}$ dan hasil uji parsial $t_{\text {hitung }}>$ $t_{\text {tabel }}(3,208>1,663)$

3. Secara simultan kualitas produk dan strategi pemasaran berpengaruh positif dan signifikan terhadap keputusan pembelian, dapat dijelaskan melalui persamaan berikut $\mathrm{Y}=3.573+0.474 \mathrm{X}_{1}+$ $0.280 \mathrm{X}_{2}$. Hasil dari uji $\mathrm{F}$ diperoleh $\mathrm{F}$ hitung $(45,318)>F_{\text {tabel }}$ (3.11) dengan konstribusi koefisien determinasi sebesar 53,7\%.

\section{Saran}

Perlu adanya penelitian lanjutan untuk dapat mengungkapkan faktor-faktor yang mempengaruhi keputusan pembelian seperti citra merek, harga kualitas layanan dan lainnya. Sehingga konsumen akan merasa puas terhadap produk-produk yang ditawarkan oleh pada PT Tri Wahana Solusindo.

\section{DAFTAR PUSTAKA}

Abdullah Thamrin dan Francis Tantri. 2016. Manajemen Pemasaran. Jakarta. PT Raja Grafindo Persada.

Agus Sriyanto,jurnal akhir, Vol. 5 No. 2 Oktober 2016 ISSN: 2252-6226, pengaruh kualitas produk, citra merek, dan kualitas layanan terhadap keputusan pembelian produk dadone, di Jakarta.

Anandya, Dudi \& Heru Suprihhadi. 2015. Riset Pemasaran : Prospektif \& Terapan. Edisi Pertama. Malang: Bayumedia Publishing.

Anggar Purna Putra, Krisnasakti. 2012. "Analisis Pengaruh Harga, Kualitas Produk, dan Promosi Terhadap Keputusan Pembelian Sepeda Motor Honda (Studi Kasus pada Konsumen di Kota Semarang)". Skripsi. Semarang: Fakultas Ekonomi dan Bisnis, Universitas Diponegoro.

Anis, Liya Monalisa. 2015. Pengaruh kualitas produk terhadap internasional Brand 
Image serta dampaknya terhadap keputusan pembelian. Jurnal Administrasi Bisnis (2015), Vol. 28, No. 2, November 2015.

Anwar, iful. 2015. Pengaruh harga dan kualitas produk terhadap keputusan pembelian "Bunchbead Kota Malang". Jurnal Ilmu dan Riset Manajemen. Vol. 4, No. 12 (2015). ISSN: 2461-0593.

Buchari Alma. 2013. Manajemen Pemasaran dan Pemasaran Jasa. Bandung. CV. Alfabeta Akbar, A. 2012. Analisis pengaruh citra merek, harga, dan kualitas produk terhadap keputusan pembelian Notebook Toshiba. Fakultas Ekonomi. Jurusan Manajemen Universitas Gunadarma, Jakarta.

Desy Irana Dewi Lubis,Jurnal Ilman, Vol. 5, No. 1, pp. 15-24, Februari 2017, ISSN 2355-1488, Pengaruh Citra Merek dan Harga terhadap Keputusan Pembelian pada Sekolah Tinggi Ilmu Manajemen Sukma .Medan.

Juwandi, Hendy Irawan. 2004. Kepuasan Pelayanan Jasa. Erlangga. Jakarta.

Kotler, Philip \& Armstrong, Gary. 2012. Prinsipprinsip pemasaran. Alih Bahasa Kotler, Philip \& Keller, Kevin L. 2012. Manajemen Pemasaran. Alih Bahasa Bob Sabran. Jakarta : Penerbit Erlangga.
Kotler, Philip \& Kevin Lane Keller (2006) "Marketing Management" Twelfth Edition,

Kotler, Philip, dan Susanto, A.B, 2012. Manajemen Pemasaran di Indonesia, Analisis, Perencanaan, Implementasi dan Pengendalian, Edisi Pertama, Jilid II, Jakarta, Penerbit Salemba Empat.

Kotler, Philip, dan Susanto, A.B, 2014. Manajemen Pemasaran di Indonesia, Analisis, Perencanaan, Implementasi dan Pengendalian, Edisi Pertama, Jilid I, Jakarta, Penerbit Salemba Empat,.

Kotler, Philip. 2005. Manajamen Pemasaran, Jilid 1 dan 2. Jakarta: PT. Indeks Kelompok Gramedia.

Lukman, Marco Dirgahadi. 2014. Analisis Pengaruh Ekuitas Merek Terhadap Keputusan Pembelian dan Kepuasan Konsumen Produk Teh Botol Sosro Kemasan Kotak. Jurnal Administrasi Bisnis (2014), Vol.10, No.1: hal. 64-81, (ISSN:0216-12 49).

Nisfiana, Dewi Nurun. 2014. Pengaruh kualitas produk terhadap kepuasan konsumen dalam membeli daging sapi (Studi pada konsumen depot daging Mubarokah. Jurnal S1 Manajemen Fakultas Ekonomi Universitas Negeri Malang. Rs 658.8342 NIS p.

Pearson Kotler, Philip. '2017. Manajemen Pemasaran di indonesia Edisi Bahasa Indonesia. Jakarta: PT. Salemba Empat. 
Ratna sari , jurnal manajerial,2016, ISSN : 1412-6613,Vol 15 no 1,pengaruh kualitas produk,citra merek,keputusan pembelian on-line,pada universitas negri Surabaya.

Susanto, Andhika H. 2013. The Influence Of Customer Purchase Decision On Customer Satisfactionand It's Impact To Customer Loyalty. Jurnal EMBA, Vol.1 No.4 Desember 2013.Swastha, Basu Dharmmesta \& Hani Handoko. 2012. Manajemen Pemasaran: Analisa Perilaku Konsumen. Edisi 1. Yogyakaarta : BPFE.

Tjiptono, Fandy. 2001. Strategi Pemasaran. Edisi Kedua. Cetakan Keenam. Yogyakarta: Penerbit. Andi.

Yogo Baskoro, jurnal akhir, 2017, ISSN:23559357, Vol.4,No 2,pengaruh citra merek dan kualitas produk terhadap keputusan pembelian pada mobil Volkswagen golf. Jakarta. 